\title{
GONADOTROPHIN CONTENT OF THE PITUITARIES OF SHEEP OF DIFFERING FERTILITY AT THREE STAGES OF THE OESTROUS CYCLE
}

\author{
R. B. LAND,* D. B. CRIGHTON† AND G. E. LAMMING $\dagger$ \\ *ARC Animal Breeding Research Organisation, Edinburgh EH9 37Q, and \\ $\dagger$ Department of Physiology and Environmental Studies, \\ University of Nottingham School of Agriculture, \\ Sutton Bonington, Loughborough, Leicestershire
}

(Received 26th January 1972, accepted 9th March 1972)

\begin{abstract}
Summary. The pituitaries of Merino $\times$ Blackface ewes were found to contain more LH at mid-cycle (Day 10 ) than Finn $\times$ Blackface ewes. The content in purebred Blackface ewes was intermediate. No differences were observed in the relative activities of FSH or $\mathrm{LH}$ in the pituitaries of the three breed types around the time of oestrus, or of FsH on Day 10 of the cycle. It is postulated that more LH may be released during mid-cycle by the more highly fertile breed type.
\end{abstract}

The Finnish Landrace breed is recognized as having a greater prolificity than British breeds of sheep (Maijala, 1966; Donald \& Read, 1967). Land (1971) has suggested that a high level of endogenous gonadotrophin stimulation may be a common factor underlying the various aspects of increased reproductive activity in Finnish Landrace sheep.

The gonadotrophin activity in the pituitaries of ewes of differing prolificity was examined in the present study. Three breed types were chosen: purebred Scottish Blackface (Blackface), Finnish Landrace $\times$ Blackface $($ Finn $\times$ Blackface) and Tasmanian Merino $\times$ Blackface (Merino $\times$ Blackface). The characteristics of the two crossbred types have been described by Donald, Read \& Russel $(1968,1970)$ and Land $(1970)$; the mean litter sizes at birth of 3-year-old Finn $\times$ Blackface and Merino $\times$ Blackface ewes were observed to be 2.30 and $1 \cdot 16$ lambs, respectively. The mean litter size of Blackface ewes under similar conditions was observed to be 1.75 (Wiener, 1967).

A group of ten ewes of each of the three breed types was established at the Animal Breeding Research Organisation Field Laboratory, Roslin, Midlothian. All ewes were kept in the same building and allocated at random to one of three similar pens. The ewes were between $4 \frac{1}{2}$ and $6 \frac{1}{2}$ years of age at the time of the experiment.

The experimental ewes were tested once a day with a vasectomized ram until all had shown at least one oestrus. Subsequently, testing was carried out thrice daily at $08.00,14.00$ and 23.00 hours; ewes which returned to oestrus 16 to 18 days after their previous oestrus were slaughtered $4 \mathrm{hr}, 36 \mathrm{hr}$ or 10 days 
after the return to oestrus. For each breed, with two exceptions (Finn $\times$ Blackface-two ewes at $4 \mathrm{hr}$; Merino $\times$ Blackface-two ewes at $36 \mathrm{hr}$ ), three ewes were killed at each of the three time intervals. In this way, nine groups were established.

All ewes were slaughtered between 6th December 1968 and 17th January 1969. The pituitaries were removed, cleaned and frozen on dry ice within $10 \mathrm{~min}$ of slaughter. Freeze-drying was commenced within $6 \mathrm{hr}$ of collection and the glands were then stored individually in a vacuum desiccator at $-15^{\circ} \mathrm{C}$ until they were assayed.

Before assay, each gland was weighed and then ground to a fine powder. Assays were performed on pooled material from each group, material from each gland being allocated to the pool in proportion to its dry weight.

The assay used for FSH was the Augmentation Assay (Steelman \& Pohley, 1953) and that for LH was the ovarian ascorbic acid depletion assay (Parlow, 1958). Both assays were employed with minor modifications only. In the case of FSH, a three-point design with one dose of unknown and two doses of standard (NIH-FSH-s7, National Institutes of Health, U.S.A.) was employed. In the case of LH, six assays were of a four-point design employing two doses of unknown and two of standard (NIH-LH-si4, National Institutes of Health, U.S.A.), and three were three-point assays.

The validity of the four-point assays and the relative potency, index of precision $(\lambda)$ and fiducial limits of error at $P=0.95$ of all assays were calculated as recommended by Sakiz \& Guillemin (1963), employing a KDF9 computer and a programme developed by Dr E. Sakiz.

The weights of the freeze-dried pituitaries did not differ significantly between the breed types or between the stages of the oestrous cycle. The mean values for the Finn and Merino crosses and Blackfaces were 175, 178 and $177 \mathrm{mg}$, respectively. At the 4-hr, 26-hr and 10-day stages of the oestrous cycle, the mean weights were 190, 180 and $161 \mathrm{mg}$, respectively.

The FSH and LH concentrations for each of the three breed types are shown in Tables 1 and 2, respectively. The concentration of FsH in the pituitaries of the three breed types can be seen to be similar when each of the stages of the oestrous cycle studied is considered separately. The concentration showed an apparent decline between 4 and $36 \mathrm{hr}$ after the onset of oestrus and remained low 10 days after onset in each case. In no case were these changes significant.

The pituitary LH concentration of the Finn $\times$ Blackface ewes was significantly less than that of the Merino $\times$ Blackface ewes on Day 10 of the oestrous cycle, that of the Blackface group being intermediate. During oestrus, however, there were no significant differences between the breed types when either of the stages was considered separately. The concentration showed an apparent decline from $4 \mathrm{hr}$ to $36 \mathrm{hr}$ in each case, although this was only significant in the case of the Blackface group.

The present results show that the known difference in the fertility of Finn $x$ Blackface and Merino $\times$ Blackface ewes is associated with a difference in the concentration of LH in their pituitaries at Day 10 of the oestrous cycle. The Finn $\times$ Blackface ewes, the litter size of which was almost twice that of the Merino $\times$ Blackface ewes, had an $\mathbf{L H}$ concentration less than half that of the 
latter at this stage of the cycle. This difference could be attributed either to a greater release of $\mathrm{LH}$ from the pituitaries of the Finn $\times$ Blackface ewes before Day 10 or to a lower rate of synthesis after pituitary depletion at oestrus. The observation that the LH activity in the urine of Finn $\times$ Blackface ewes was over three times $(P<0.05)$ that of Merino $\times$ Blackface ewes during Days 9, 10

TABLE 1

THE FSH CONTENT OF THE PITUITARIES OF EXPERIMENTAL EWES

\begin{tabular}{c|l|c|c}
\hline $\begin{array}{c}\text { Time after onset } \\
\text { of oestrus }\end{array}$ & \multicolumn{1}{|c|}{ Breed type } & $\begin{array}{c}\text { Pituitary FSH content* } \\
(\mu g \text { NIH-FSH-S7/mg dry weight })\end{array}$ & $\lambda$ \\
\hline \multirow{2}{*}{$4 \mathrm{hr}$} & Finn $\times$ Blackface & $11.49(5 \cdot 14$ to $18 \cdot 20)$ & $0 \cdot 18$ \\
& Blackface & $13.44(0.37$ to 33.49$)$ & $0 \cdot 31$ \\
$36 \mathrm{hr}$ & Merino $\times$ Blackface & $12 \cdot 69(5.87$ to $20 \cdot 74)$ & $0 \cdot 18$ \\
& Finn $\times$ Blackface & $6 \cdot 10(2 \cdot 77$ to $9 \cdot 61)$ & $0 \cdot 19$ \\
& Blackface & $7 \cdot 95(2 \cdot 68$ to 13.97$)$ & $0 \cdot 20$ \\
10 days & Merino $\times$ Blackface & $6 \cdot 67(3.22$ to $10 \cdot 56)$ & $0 \cdot 19$ \\
& Finn $\times$ Blackface & $6 \cdot 28(2.92$ to $9 \cdot 92)$ & $0 \cdot 19$ \\
& Blackface & $8.79(4.90$ to $14 \cdot 38)$ & $0 \cdot 19$ \\
& Merino $\times$ Blackface & $6.08(2 \cdot 73$ to $9 \cdot 56)$ & $0 \cdot 19$ \\
\hline
\end{tabular}

* Figures in parentheses are fiducial limits of error at $P=0.95$.

TABLE 2

THE LH GONTENT OF THE PITUITARIES OF EXPERIMENTAL EWES

\begin{tabular}{|c|c|c|c|}
\hline $\begin{array}{c}\text { Time after onset } \\
\text { of oestrus }\end{array}$ & Breed type & $\begin{array}{c}\text { Pituitary LH content* } \\
(\mu g \mathcal{N} I H-L H-S 14 / m g \text { dry weight })\end{array}$ & $\lambda$ \\
\hline $4 \mathrm{hr}$ & $\begin{array}{l}\text { Finn } \times \text { Blackface } \\
\text { Blackface } \\
\text { Merino } \times \text { Blackface }\end{array}$ & $\begin{array}{l}30.64(25.09 \text { to } 38.12) \\
26.34(21.56 \text { to } 32.56) \\
29.01(23.61 \text { to } 36.16)\end{array}$ & $\begin{array}{l}0.08 \\
0.08 \\
0.08\end{array}$ \\
\hline $36 \mathrm{hr}$ & $\begin{array}{l}\text { Finn } \times \text { Blackface } \\
\text { Blackface } \\
\text { Merino } \times \text { Blackface }\end{array}$ & $\begin{array}{l}19.32(11.46 \text { to } 36.08) \\
14.21(9.29 \text { to } 21.52) \\
17.13(10.24 \text { to } 31.00)\end{array}$ & $\begin{array}{l}0.26 \\
0 \cdot 21 \\
0 \cdot 26\end{array}$ \\
\hline 10 days & $\begin{array}{l}\text { Finn } \times \text { Blackface } \\
\text { Blackface } \\
\text { Merino } \times \text { Blackface }\end{array}$ & $\begin{array}{l}21.16(15.26 \text { to } 29 \cdot 34) \\
27.39(20.34 \text { to } 36.90) \\
44.37(34.85 \text { to } 56.48)\end{array}$ & $\begin{array}{l}0 \cdot 15 \\
0 \cdot 15 \\
0 \cdot 12\end{array}$ \\
\hline
\end{tabular}

* Figures in parentheses are fiducial limits of error at $P=0.95$.

and 11 of the oestrous cycle (R. B. Land \& H. A. Robertson, unpublished data) indicates that the differences in pituitary concentration observed reflect different rates of release. The urinary LH estimations are also compatible with the present data in that no differences were observed between breed types in urinary LH activity at oestrus.

It appears, therefore, that Finn $\times$ Blackface ewes which have a greater litter size when compared with Merino $\times$ Blackface ewes exhibit a greater LH release during part of the oestrous cycle but not during the oestrous period itself. Evidence has thus been obtained for a higher level of gonadotrophin stimulation in Finn $\times$ Blackface ewes at one stage of the cycle. The significance of these observations in terms of the control of the development of ovarian follicles and ovulation rate merits further investigation. 
The authors are indebted to Miss Anne Lister for skilled technical assistance and to Schering Chemicals Ltd and the National Institutes of Health, U.S.A., for supplies of hormones.

\section{REFERENCES}

Donald, H. P. \& Read, J. L. (1967) The performance of Finnish Landrace sheep in Britain. Anim. Prod. 9,471 .

Donald, H. P., Read, J. L. \& Russel, W. S. (1968) A comparative trial of crossbred ewes by Finnish Landrace and other sires. Anim. Prod. 10, 413.

Donald, H. P., ReAd, J. L. \& Russel, W. S. (1970) Influence of litter size and breed of sire on carcass weight and quality of lambs. Anim. Prod. 12, 281.

LAND, R. B. (1970) A relationship between the duration of oestrus, ovulation rate and litter size of sheep. 7. Reprod. Fert. 23, 49.

LAND, R. B. (1971) The incidence of oestrus during lactation in Finnish Landrace, Dorset Horn and Finn-Dorset sheep. F. Reprod. Fert. 24, 345.

Maijala, K. (1966) Causes of variation in litter size of Finn-sheep ewes. 9th Int. Congr. Anim. Prod. Edinburgh, Abstract p. 29. Oliver \& Boyd, Edinburgh.

Parlow, A. F. (1958) A rapid bioassay method for $\mathrm{LH}$ and factors stimulating LH secretion. Fedn Proc. Fedn Am. Socs exp. Biol. 17, 402.

Sakiz, E. \& Guillemin, R. (1963) On the method of ovarian ascorbic acid depletion as a test for luteinizing hormone (LH). Endocrinology, 72, 804.

Steelman, S. L. \& Pohley, F. M. (1953) Assay of the follicle stimulating hormone based on the augmentation with human chorionic gonadotropin. Endocrinology, 53, 604.

WIENER, G. (1967) A comparison of the body size, fleece weight and maternal performance of five breeds of sheep kept in one environment. Anim. Prod. 9, 177. 